\title{
パラオ共和国での造成地を含む小流域における 土砂流出の現地観測およびGeoWEPPの適用

\author{
FIELD OBSERVATION AND NUMERICAL SIMULATION USING GEOWEPP \\ FOR SEDIMENT RUNOFF DUE TO LAND DEVELOPMENT IN A SMALL \\ WATERSHED, REPUBLIC OF PALAU
}

\author{
工藤将志 1 ・大澤和敏 2 松井宏之 2 ・菅和利 3 ・佐藤航太郎 4 ・池田駿介 5 \\ Masashi KUDO, Kazutoshi OSAWA, Hiroyuki MATSUI, Kazutoshi KAN, Kotaro SATO, \\ Syunsuke IKEDA

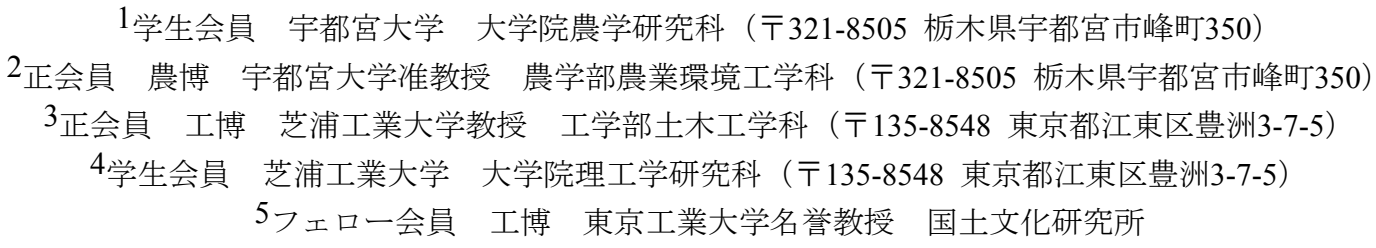 \\ ( ₹103-0013 東京都中央区日本橋人形町2-15-1)
}

\begin{abstract}
Soil erosion and runoff have led to environment problems in Babeldaob Island, Republic of Palau, and practical simulation model which can evaluate soil erosion and sediment runoff in watershed area is necessary. This paper aims to quantify the sediment movements in a watershed through continuous field observation for two years and numerical simulation using GeoWEPP model. We focused the small catchment in Ngerikiil watershed which has 2.7 ha of developing bare land. The following three points were clarified. First, field observed results showed that severe soil erosion at the land development zone affects the behavior of sediment movements in the watershed. Second, GeoWEPP model has high applicability in predicting sediment runoff at two distinctive watersheds. One has no land development and another has developing bare land. Third, the GeoWEPP model gave the reasonable spatial distribution of soil erosion in the watershed.
\end{abstract}

Key Words : sediment runoff, soil erosion, land development, field observation, WEPP model, Republic of Palau

\section{1. 序論}

海域における貴重な生態系を構成し，外見的な価值を 有するサンゴ礁は，近年，人間活動に由来する負の影響 を受けている．代表的な影響として，海水温の上昇によ る白化，オニヒトデ等による食害，陸域からの土砂流出 による光合成阻害，農地，工場，家庭の排水に含まれる 栄養塩や污染物質による成長阻害が挙げられる。 世界中 のサンゴ礁の $22 \%$ 垬侵食と陸域由来の污染の影響を 受けており 1$)$ ，また陸域での開拓が進んだ国では50\%が 危機に晒されているとも報告されている2).

ミクロネシアに属するパラオ共和国では，現在，観光 業が発展段階にある. 外国人入国者数は，2001年に比べ， 2011年にはおよそ2倍の11万人となった.さらに2012年,
隆起サンゴ礁でできた島々は世界複合遺産に指定された。 それに伴い，バベルダオブ(Babeldaob)島では土地開発が 促進される見込みである. 過去の大規模な造成行為を挙 げる. 1984年，ガリキル(Ngerikiil)流域内にパラオ国際 空港が建設され，2003年には新ターミナルが建設された。 2006年，首都がコロールからマルキョク(Melekeok)へ移 転された際にも大規模な造成が行われた．2007年，バベ ルダオブ島を一周する幹線道路が建設された. 以上のよ うな土地開発行為によって, 土壤が露出した土地では土 壤侵食が増大する. また熱帯地方に特有の活発な降雨に よって流出した多量の土砂がマングローブ林を通過して 沿岸域まで流出することで，観光資源であるサンゴ礁に 悪影響を与えることが懸念されている.

パラオ共和国における土砂流出によるサンゴ礁への影 響を示した研究事例として，Golbuuらは，ガリキル川河 


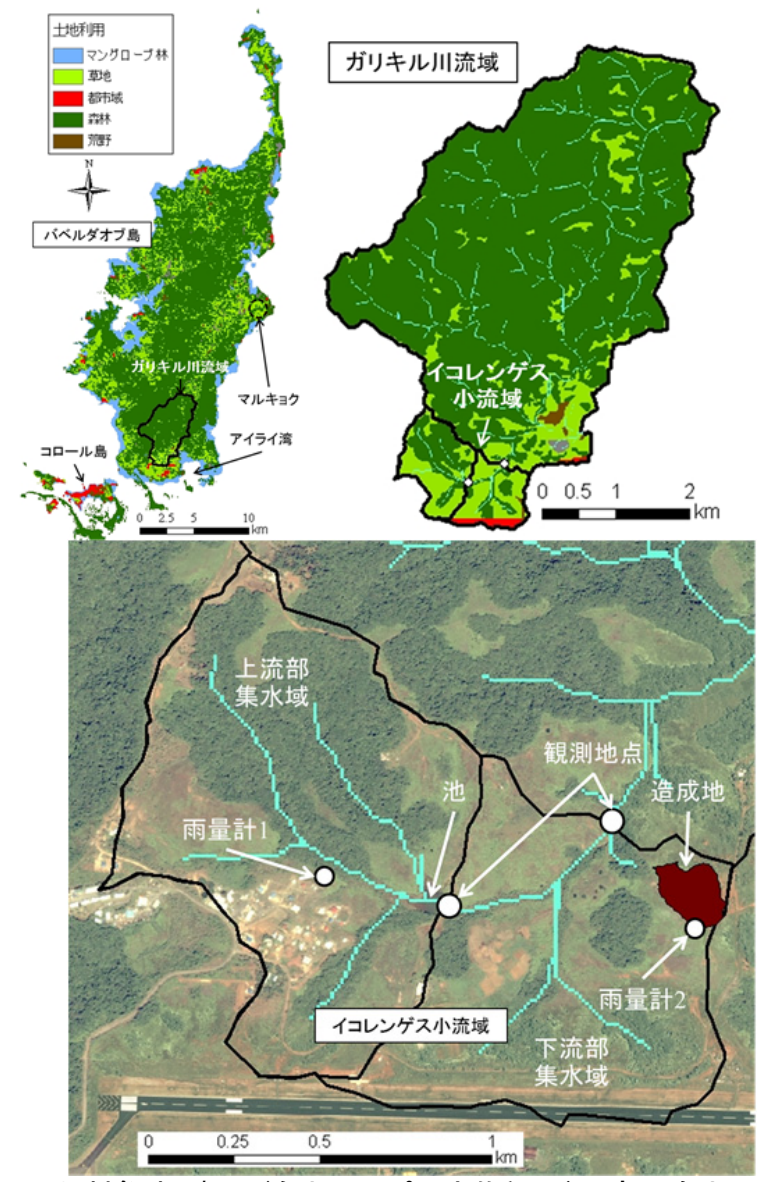

図-1 対象地の概要(左上図 : パラオ共和国主要部，右上図 : ガ リキル流域，下図 : イコレンゲス小流域)

口のアイライ(Airai)湾では150 t/ $\mathrm{km}^{2} / \mathrm{y}$ の土砂が堆積して いると推定し，サンゴ礁が土砂に覆われていたことを報 告した3). また，ガリキル流域において河口域に流入し た土砂量の15 30\%がマングローブ林に捕捉され，さら に $98 \%$ \%゙アライ湾の外に流出せずに, 湾内で堆積した と報告した4). Victorらは，ガルドルク(Ngerdorch)流域に おいて河口域に流入した土砂量の 28 44\%がマングロー ブ林に捕捉されたと報告した ${ }^{5}$. Golbuuらは，沿岸域に おける土砂の堆積量や浮遊物質濃度とサンゴの個体数や 個体密度には相関があると報告し6)，パラオ共和国にお ける土砂流出がサンゴ礁に悪影響を与えていることを示 した. 土砂の主な発生源の一つである造成地(裸地)にお ける土壌侵食および流域の土砂流出を対象とした研究事 例として, 工藤らは, ガリキル流域の河川における土砂 流出の現地観測より，造成地からの土壌侵食量を556 tha/y(2010年12月 2011年11月)と推定した7).さらに WEPP (Water Erosion Prediction Project)による土砂流出解 析から，造成地における土壌侵食抑制対策の効果を算定 したが，モデルの適合性は検証されていない．Maalimら は，GeoWEPPを用いて流域における水および土砂動態 に与える土地利用変化の影響を解析し，草地流域から農 地流域への変化によって水および土砂の流出が増加した ことを示した ${ }^{8)}$ が，モデルの適合性は検証されていない． そこで本研究では，パラオ共和国ガリキル流域の造成

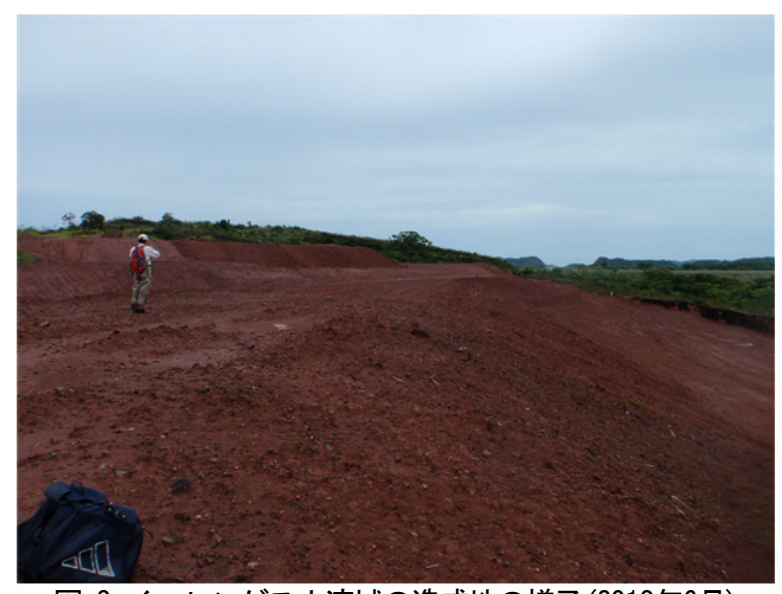

図-2 イコレンゲス小流域の造成地の様子(2012年6月)

地を含む小流域における土砂流出の2年間の現地観測結 果を基に, 土袞侵食・土砂流出モデルであるGeoWEPP を用いて流域土砂動態を解析し，その適合性を検証する ことを目的とした．なお本研究では，サンコ礁が分布す る沿岸域まで流出し得る浮遊砂およびウォッシュロード の流出のみに着目し, それらの流出を土砂流出と称す.

\section{2. 方法}

\section{(1) 対象地の概要および土砂流出の観測方法}

パラオ共和国バベルダオブ島ガリキル流域南部のイコ レンゲス小流域を対象とした。 その概要を図-1に示した。 そこでは，2010年9月に裸地状態であることを確認して 以来, 2013 年3月時点まで裸地状態の造成地が存在して いる. 造成地の写真を図-2に示した. この造成地では, 重機による整地作業によって一様な傾斜からテラス状へ 地形の改変が進んだが，建造物の構築等の進展はなかっ た. 開発の停滞の理由, 整地作業の頻度, 改変後の地形 の形状についての明確な情報は得られなかった。

造成地が含まれないイコレンゲス小流域の上流部を集 水域とする上流地点と，造成地が含まれるイコレンゲス 小流域全体を集水域と寸る下流地点を河川内に設置し, 水深, 流速, 濁度の連続計測を2011年1月から2012年12 月まで，工藤ら ${ }^{7}$ と同じ方法で行った。設置された濁度 計による計測と同時に採取した水試料からSS濃度を分析 することで得られた濁度-SS濃度関係式 $(S S$ 濃度 $(m g / L)=$ 0.998×濁度 $\left.(m g-k a o l i n / L) ， \mathrm{R}^{2}=0.989\right)$ を用いて， SS濃度の 連続值を算出した，そのSS濃度に流量を乗じたものを土 砂流出量とした. なお，濁度とSS濃度に高い相関が見ら れたため, 濁度からSS濃度への変換に粒度は考慮しな かった. また，降水量は図-1に示した2箇所で観測した が, 各々の降水量に差が見られなかったことから, 雨量 計1の観測結果を用いた. 使用した計測機器を表-1に, 各観測地点の集水域における土地利用を表-2に示した. 土地利用は，造成地を除いたほとんごの部分が自然状態 の森林および草地で構成され，未利用の土地が多い. 
表-1 計測機器

\begin{tabular}{ccc}
\hline 項目 & 種類 & 品名 \\
\hline 雨量 & 転倒升式雨量計 & RG3-M(Onset 社) \\
\hline 水位 & 圧力式水位計 & U20-001-01-Ti (Onset 社) \\
\hline 流速 & $\begin{array}{c}\text { 二次元電磁 } \\
\text { 流速計 }\end{array}$ & $\begin{array}{c}\text { Compact EM } \\
\text { (JFE アドバンテック社) }\end{array}$ \\
\hline 濁度 & $\begin{array}{c}\text { 光学式濁度計 } \\
\text { (後方散乱) }\end{array}$ & Compact CLW \\
& & (JFE アドバンテック社)
\end{tabular}

表-2 各観測地点の集水域における土地利用

\begin{tabular}{ccc}
\hline & 上流地点集水域 & 下流地点集水域 \\
\hline 流域面積 & $99 \mathrm{ha}$ & $170 \mathrm{ha}$ \\
\hline 森林 & $49 \mathrm{ha}(49 \%)$ & $65 \mathrm{ha}(38 \%)$ \\
\hline 草地 & $50 \mathrm{ha}(51 \%)$ & $102 \mathrm{ha}(60 \%)$ \\
\hline 造成地 & - & $2.7 \mathrm{ha}(1.6 \%)$ \\
\hline
\end{tabular}

\section{(2) GeoWEPPIよる流域土砂動態の解析方法 a) GeoWEPPの概要}

GeoWEPPを用いて，対象流域の流域土砂動態を解析 した. GeoWEPPは，USDAによって開発されたWEPPを GIS と連動した形に改良された土壌侵食・土砂流出モデ ルである9), 10)。なお，WEPPでは掃流砂成分の運搬過程 は考慮されていないため，計算される土砂流出量は浮遊 砂およびウォッシュロード成分である. GeoWEPPにお ける計算の流れを図-3に示した。解析機構であるWEPP は，侵食および侵食に関して大きな影響因子である植物 の生長，土壤状態の変化，各種土地管理作業を実際の現 象に即した形で表現している ${ }^{11)}$ 。また，GeoWEPPは WEPPの制限要因であった流域スケールにおける適用の 作業性を格段に向上させている. 本来WEPPでは，斜面 や水路などの流域要素の描画や各種パラメータの入力を 要素ごとに手動で行う必要があった。一方，GeoWEPP による解析では，TOPAZ (TOpographic PArameteriZation) を利用することで地形データ(DEM)から必要な情報を抽 出して，自動で斜面や水路等の流域要素を描画すること ができる。また，土壤図や土地利用図をもとにWEPPの 土壌や土地管理入力データを自動入力可能である.

\section{b) 入力情報の整備および解析手順}

GeoWEPPに入力する気象, 地形, 土壤, 土地管理 データを整備した。気象データについては，BPCDG (BreakPoint Climate Data Generator)を用いて2011年1月か ら2012年12月までの降水量観測值が反映された気象入力 情報を作成した．気象データの作成に必要な気象情報は， 降水量, 最高・最低気温, 日射量, 風速, 風向, 露点温 度である. 降水量には，観測された1時間降水量を使用 した，観測されていない最高・最低気温，風速，風向は NOAA NCDCから入手し，日射量と露点温度はWEPPの データベースにあるコロールの月平均值で代用した。地 形および土壌データについては，10mメッシュのDEMお よび土壤困をUSDA NRCSより入手した。対象流域に存 在する全12種の土壌の土性や有機物含有率等の物性值や

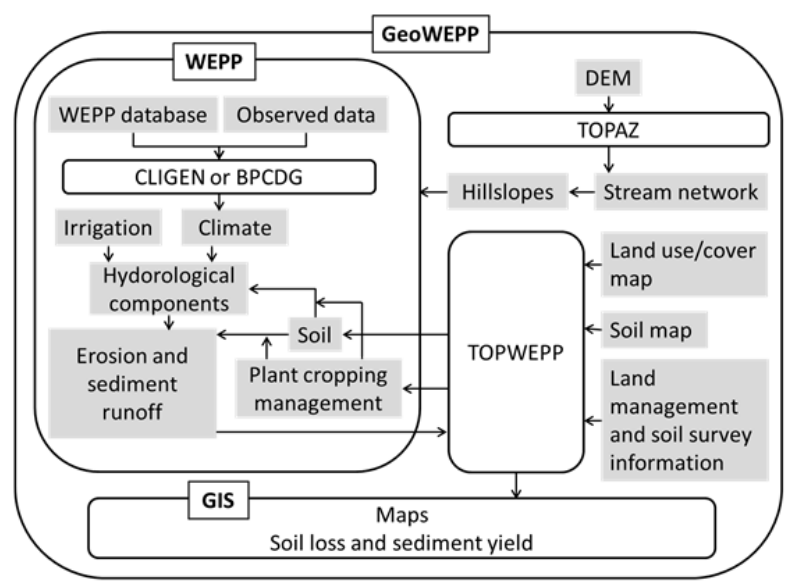

図-3 GeoWEPPにおける計算の流れ

表-3 土壌侵食および土砂流出に関するパラメータ

\begin{tabular}{ccc}
\hline 項目* & 数值 & 単位 \\
\hline インターリル侵食係数, $K_{i b}$ & $4.18 \times 10^{6} \sim 5.28 \times 10^{6}$ & $\mathrm{~kg} \cdot \mathrm{s} \cdot \mathrm{m}^{-4}$ \\
\hline リル侵食係数, $K_{r b}$ & $0.0057 \sim 0.0136$ & $\mathrm{~s} \cdot \mathrm{m}^{-1}$ \\
\hline 限界掃流力, $\tau_{c b}$ & $3.16 \sim 3.50$ & $\mathrm{~Pa}$ \\
\hline 有効透水係数, $K_{b}$ & $1.00 \sim 9.17$ & $\mathrm{~mm} \cdot \mathrm{h}^{-1}$ \\
\hline *各項目は土袞種毎の固有の值である「基淮值(baseline)」を表す.
\end{tabular}

侵食係数, 限界掃流力, 有効透水係数等の土壌侵食およ び土砂流出に関するパラメータは, USDAのSSURGO データベースを参照し，2006年の調査結果を使用した。 土畩侵食および土砂流出に関するパラメータを表-3に示 した．また，土地利用図をJICAパラオ支所より入手し， 土地管理データを作成した，植生等のパラメータは, WEPPのデータベースを参照しデフォルト值を使用した

GeoWEPPを用いた流域土砂動態の解析手順を以下に 示す. (1) DEM, 土壤図, 土地利用困のGISデータを GeoWEPP 入力し，TOPAZにより斜面および流路を描 画した。 上流地点の集水域には16個の斜面と6個の流路, 下流地点の集水域には32個の斜面と13個の流路で構成さ れた。(2) 上流地点の上流側に池(図-1)が存在している が，GeoWEPPのインターフェースでは貯水池の描画が 不可能であるため, 貯水池を手動で加えた. 貯水池の形 状等のパラメータは現況に即して設定した。(3) 土砂流 出量の解析結果を観測值と比較し, 降雨イベント毎およ び年毎で適合性の検証を行った。適合性の指標として Nash-Sutcliffe係数 ${ }^{12)}$ (以下, NS係数)を用いた. なお，NS 係数は，流出解析等のモデル適合性を評価する指標とし てよく用いられ，0.7以上の值が良好な適合性を示すと 考えられている. さらに，流域内での土畩侵食量の空間 分布を示し，造成地における侵食量について検討した.

\section{3. 結果および考察}

\section{(1) 土砂流出の現地観測}

対象流域における降水量と，上流地点および下流地点 における土砂流出量の累積值を図-4に，平水時流量，最 大流量, 総流量を表-4に示した。降水量は，2011年が多 


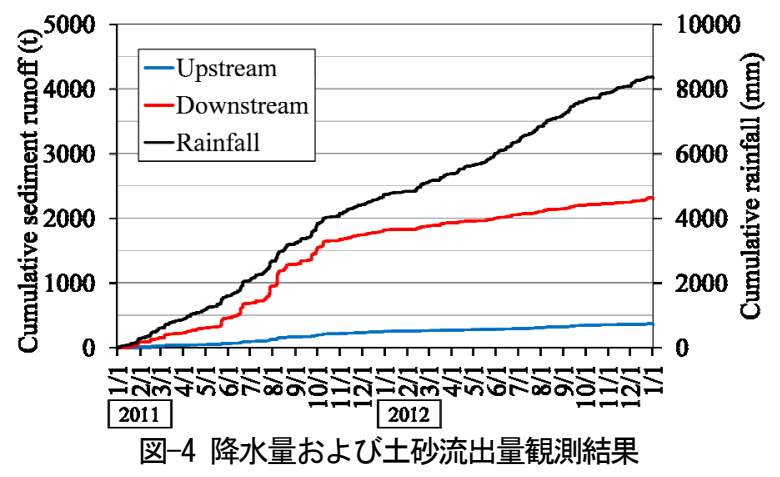

表-4 流量観測結果の概要

\begin{tabular}{ccccc}
\hline 観測地点 & \multicolumn{2}{c}{ 上流地点 } & \multicolumn{2}{c}{ 下流地点 } \\
観測年 & 2011 & 2012 & 2011 & 2012 \\
\hline \hline 平水時流量 $^{*}$ & $0.04 \sim 0.05$ & $0.02 \sim 0.03$ & $0.08 \sim 0.09$ & $0.05 \sim 0.06$ \\
\hline 最大流量 $^{*}$ & 4.49 & 2.30 & 15.53 & 6.13 \\
\hline 総流量 $^{* *}$ & 3.23 & 1.97 & 5.26 & 3.16 \\
\hline & & & $*$ 単位 $: \mathrm{m}^{3} / \mathrm{s}, * *$ 単位 $: \mathrm{Mm}^{3} / \mathrm{y}$
\end{tabular}

雨年で4725mm，2012年は平年並みで3636mmであった。 また，5月から10月にかけて降水量が大きい傾向が見ら れた．流量の観測值も両流域ともに2011年の方が2012年 よりも大きかった. 特に2011年の最大流量は上流地点で は2012年の約2倍，下流地点では約2.5倍であった。土砂 流出量は，上流地点では2011年に249 t，2012年に118 t, 下流地点では2011年に1818 t，2012年に494 tが観測され た。降水量が平年並みであった2012年では，多雨年で あった2011年と比較して上流地点，下流地点ともに土砂 流出量は小さかった．2年間の土砂流出量を合計すると， 上流地点では367 t, 下流地点では2312 tとなり, 下流地 点の土砂流出量は上流地点と比較して著しく大きかった. 各地点の流域面積を考慮すると，下流地点での土砂流出 量が大きかったのは，造成地からの顕著な土砂流出によ るものと考えられる. なお，無降雨時の土砂流出量の2 年間の合計值は上流地点で74 t, 下流地点で135 tであり, 土砂流出は主に降雨時に発生していた。

下流地点において，2011年の5月から10月における土 砂流出が顕著であった。 これは，造成地が開発されて間 もなくの時期に，大きな降水量および降雨強度を有する 降雨イベントが集中したため，土壤の攪乱による土壌侵 食の増大が著しかったためと考えられる。また，河川流 量が著しく増大したため, 河道に堆積していた土砂の再 懸濁が顕著になったことも要因と考えられる，一方， 2012年の5月から10月では，2011年のような土砂流出量 の突発的な増大は見られなかった。これは，2012年の降 水量が2011年と比較して小さかったため, 土壌侵食量も 小さかったことが第一の要因と考えられる．それに加え， 造成地における前年の顕著な土壌侵食によって，表面土 畩の粗粒化が進み，土壤侵食量が減少傾向にあったこと も予想される.さらに，図-2に示したように造成地にお ける重機による整地作業が進行し，地形が一様な傾斜か らテラス状に改変されたことによって，造成地における 土壌侵食量が抑制されたことも考えられる. その他,
2012年は流量が2011年よりも小さい傾向にあったため, 河道における土砂の運搬能力が低下し，下流地点におけ る土砂流出量が比較的小さかったことが考えられる.

\section{(2) GeoWEPPIよる流域土砂動態の解析}

\section{a) 土砂流出解析における適合性の検証}

GeoWEPPにより降雨イベント毎の土砂流出量を解析 し，その適合性を観測結果を用いて検証した。土砂流出 量の観測值が大きかった2011年の降雨イベント毎の土砂 流出量を図-5に示した(2012年は頁数の制約のため省略). 降雨イベントは101回あった。降雨イベントの定義とし て, USLE (Universal Soil Loss Equation)で一連降雨の定義 として用いられている「降水量が $12.7 \mathrm{~mm}$ 以上または降 雨強度が $6.4 \mathrm{~mm} / 15 \mathrm{~min}$ 以上の降雨で，降雨後の無降雨期 間が6時間以上」 ${ }^{13)}$ を採用した。降雨イベント毎の土砂 流出量の観測值が最大で約18 tであった上流地点では, 降雨イベントの大小に関わらず，その適合性は良好で あった. 降雨イベント毎の土砂流出量の観測值が最大で 約170 tであった下流地点においても，降雨イベントの大 小に関わらず適合性は良好であった．NS係数を算定し たところ，上流地点で $0.83 ，$ 下流地点で 0.80 であり，適 合性が高いと評価できる。また，2年間を通したNS係数 は，上流地点では0.76，下流地点では0.70であった。

2012年も含めた全期間における降雨イベント毎の土砂 流出量の観測值と計算值の関係を図-6および図-7に示し た．上流地点において，2011年では適合性は高かったが， 2012年ではNS係数は0.11であり適合性が低かった。これ は小さな降雨イベントにおいて，流量や土砂流出量の計 算值がゼロまたはほぼゼロであったイベントが多くあっ たためと考えられる。下流地点においても，2011年では 適合性が高かったが，2012年においてはNS係数が-2.38 であり，適合性は著しく低く過大評価の傾向が見られた。 これは造成地における表面土壤の粗粒化を，WEPPでは 表現できないことが挙げられる．また，観測期間中に造 成地のテラス化が進み地形が徐々に変化していったが, 地形の変化の時期および形状が不明のため，2011年時点 の現況を全期間通して設定したことで，地形変化に伴う 土壤侵食量を正確に評価できなかったことも考えられる。 流量および土砂流出量の総量を表-5に示した。総流量 の相対誤差は+8 +21\%であり，計算值は過大評価する傾 向にあった．総土砂流出量の相対誤差は，2012年の下流 地点を除いて，-24 -11\%であり，計算值は過小評価する 傾向にあった。一方，2012年の下流地点の相対誤差は $+61 \%$ となり，計算值は著しい過大評価であった.

以上のように，小流域におけるWEPPによる土砂流出 量の計算值の適合性は概ね良好であった。 各種入力デー タの整備およびWEPPの土㙵侵食・土砂流出の応答が適 切であったと考えられる. しかし, 著しい土畩侵食に伴 う表面土壌の粗粒化や地形の変形を解析条件に反映でき なかったためと考えられる誤差が生じた. 

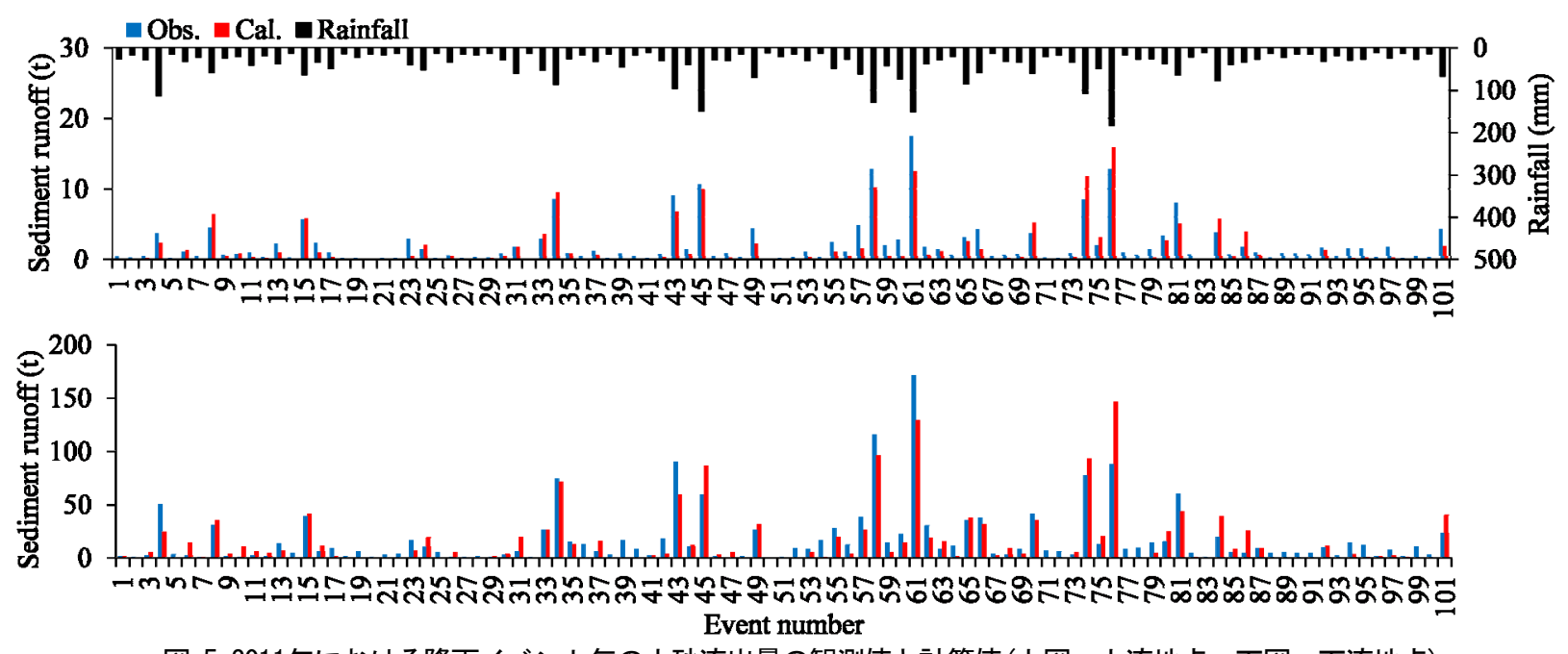

図-5 2011年における降雨イベント毎の土砂流出量の観測値と計算値(上図 : 上流地点, 下図 : 下流地点)

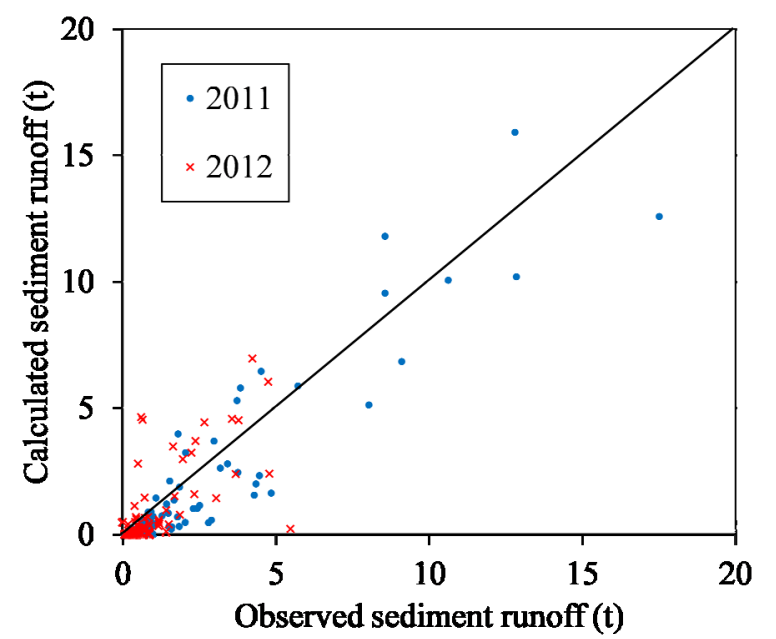

図-6 上流地点における土砂流出量の観測値と計算値の関係

\section{b）土壤侵食量の空間分布}

WEPPによって算出された2011年および2012年のイコ レンゲス小流域における土䁃侵食量の空間分布を図-8に 示した. 2011年では，造成地の斜面を除いた全ての斜面 において土壤侵食量が3 7 tha/yであった。一方，造成地 の斜面における土壤侵食量は448 tha/yであり，造成地に おける顕著な土壌侵食を表現可能であった. 2012年では, 造成地の斜面を除く全ての斜面で土壌侵食量は2 4 t/ha/y であり，造成地の斜面における土壌侵食量は258 tha/yで あった. 2011年と比較して2012年では全体的に土㙵侵食 量が小さかった. その要因として，2012年が2011年より 少雨であったことが挙げられる.

観測結果を用いて造成地における土壌侵食量を推定す ると，2011年に518 tha/y，2012年に109 tha/yであった. なお，その推定方法は，造成地以外の全ての斜面におけ る単位面積当たりの土砂流出量は，上流地点において観 測された単位面積当たりの土砂流出量と同量と仮定し, 下流地点で観測された土砂流出量から造成地以外の斜面 における土砂流出量を差し引くことによって, 造成地に おける土壤侵食量とした。この結果とWEPPによる解析

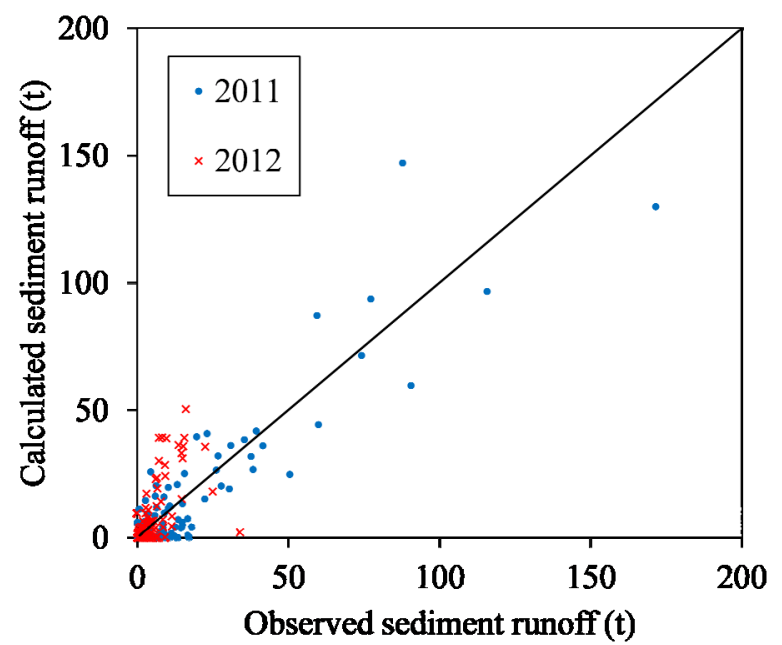

図-7 下流地点における土砂流出量の観測值と計算値の関係

表-5 降雨イベントにおける総流量および総土砂流出量

\begin{tabular}{|c|c|c|c|c|}
\hline \multirow{3}{*}{$\begin{array}{l}\text { 地点 } \\
\text { 期間 }\end{array}$} & \multicolumn{4}{|c|}{ 上流地点 } \\
\hline & \multicolumn{2}{|c|}{2011} & \multicolumn{2}{|c|}{2012} \\
\hline & 観測值 & 計算值 & 観測值 & 計算值 \\
\hline 総流量 $\left(\mathrm{Mm}^{3} / \mathrm{y}\right)$ & 1.92 & 2.07 & 1.04 & 1.16 \\
\hline 総土砂流出量 (t/y) & 207 & 157 & 86 & 76 \\
\hline 地点 & \multicolumn{4}{|c|}{ 下流地点 } \\
\hline 期間 & \multicolumn{2}{|c|}{2011} & \multicolumn{2}{|c|}{2012} \\
\hline & 観測值 & 計算值 & 観測值 & 計算值 \\
\hline 総流量 $\left(\mathrm{Mm}^{3} / \mathrm{y}\right)$ & 2.85 & 3.36 & 1.51 & 1.83 \\
\hline 総土砂流出量 $(\mathrm{t} / \mathrm{y})$ & 1700 & 1511 & 477 & 766 \\
\hline
\end{tabular}

結果を比較すると，2011年では造成地における侵食量を 概ね良く再現していたが(相対誤差-14\%)，2012年では著 しい過大評価であった(相対誤差+137\%)。このことから もWEPPによる2012年の解析值には, 土壌の粒度組成の 変化や経時的な地形の変化を表現することができないこ となどによる誤差が多分に含まれていると考えられる.

以上の結果から, 本解析で用いたGeoWEPPは, 流域 内の斜面における土壤侵食量の空間分布を明確に把握す ることができる手法であると言える．ただし，これらの 解析結果には, 前述のような誤差が含まれ得る. 

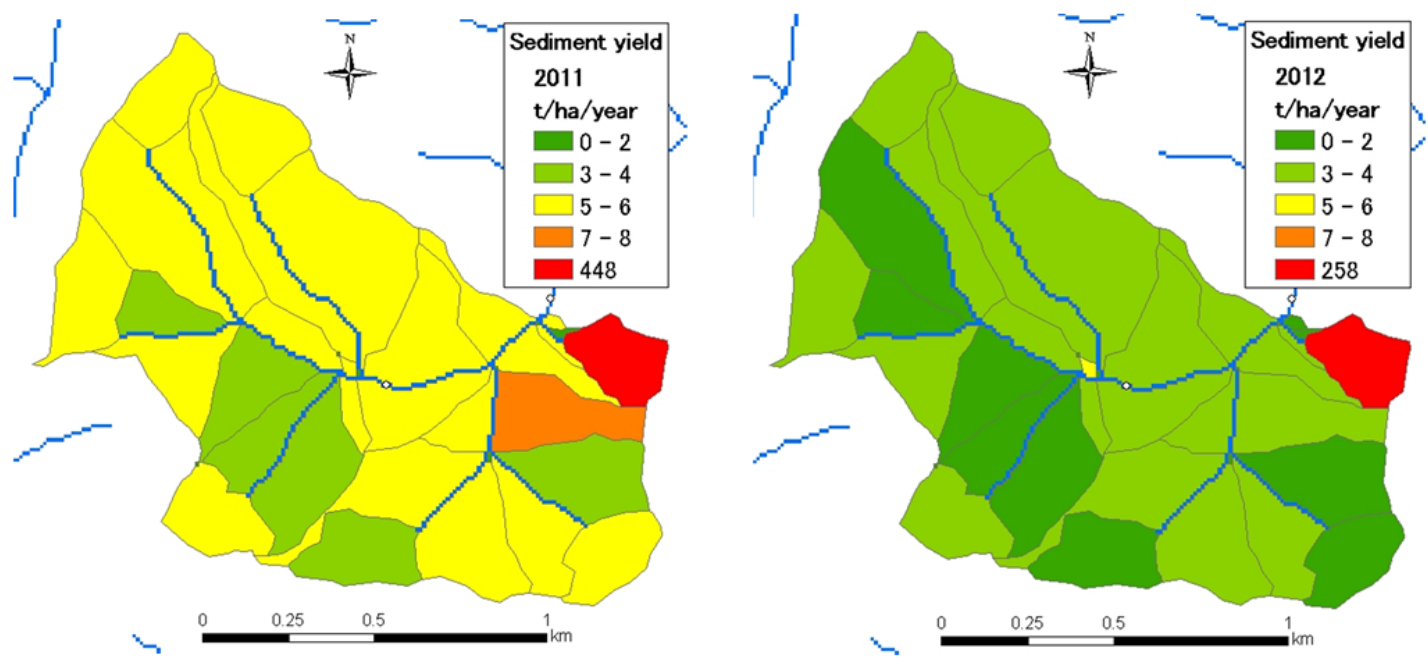

図-8 イコレンゲス小流域における土袞侵食量の空間分布(左図 : 2011年，右図 : 2012年)

\section{4. 結論}

パラオ共和国の造成地を含む小流域における 2 年間の 土砂流出観測結果を基に，土壌侵食や土砂流出の広域評 価モデルであるGeoWEPPを用いた流域土砂動態の解析 における適合性を検証した。その結果を以下にまとめた。 1) 2 年間の観測結果から，上流地点では367 t, 下流地点 では2312 tの総土砂流出量が算出され，造成地を含む 集水域からの土砂流出量は著しく大きかった，造成 地では表面土壌の粗粒化や地形のテラス化によって 土畩侵食量が減少傾向にあることが示唆された。

2) 森林と草地で構成される小流域と造成地からの土砂 流出が著しい小流域の両流域において, GeoWEPPに よる土砂流出量の計算值は，観測值と概ね適合した。 一方，造成地を含む流域では，造成地における表面 土壤の粗粒化や地形のテラス化を解析条件に反映で きなかったためと考えられる誤差が生じた期間が あつた。

3) GeoWEPPによる解析の結果，流域内の斜面における 土畩侵食量の空間分布を明示することができた.

今後，ガリキル流域全域，その他主要流域，そしてバ ベルダオブ島全域へGeoWEPPを適用し, 土砂動態の広 域評価が期待される。.また，将来的な土地開発計画を想 定した場合の土砂動態変化を，GeoWEPPを用いて予測 および評価することが期待される．一方で，GeoWEPP による解析ではサンゴ礁が存在する沿岸域までの土砂動 態は解析できない. 土砂の発生源から沿岸域までを一体 とした流域一貫土砂動態の解析手法の確立が望まれる.

謝辞: 本研究は日本学術振興会科学研究費補助金基盤研 究(B)(課題番号 : 22404010, 研究代表者 : 菅和利), 日本 学術振興会学術研究助成基金助成金基盤研究 $(\mathrm{C})($ 課題番 号 : 25450354, 研究代表者 : 大澤和敏)の支援によって 行われた.

\section{参考文献}

1)Bryant, D., Burke, L., McManus, J., Spalding, M.: Reef at risk: A map-based indicator of threats to the world's coral reefs, World Resource Institute Report, World Resource Institute, 1998.

2)Burke, L., Selig, L., Spalding, M.: Reef at risk in southeast Asia, World Resource Institute Report, World Resource Institute, 2002.

3) Golbuu, Y., Wolanski, E., Harrison, P., Richmond, R.H., Victor, S., Fabricius, K.E.: Effect of Land-Use Change on characteristics and Dynamics of Watershed Discharge in Babeldaob, Palau, Micronesia. Journal of Marine Biology, article ID 981273, 17pages, 2011.

4)Golbuu, Y., Victor, S., Wolanski, E., Richmond, R.H.: Trapping of fine sediment in a semi-enclosed bay, Palau, Micronesia. Estuarine, Coastal and Shelf Science, 57, 941-949, 2003

5) Victor, S., Golbuu, Y., Wolanski, E., Richmond, R.H.: Fine sediment trapping in two mangrove-fringed estuaries exposed to contracting land-use intensity, Palau, Micronesia. Wetlands Ecology and Management, 12, 277-283, 2004

6) Golbuu, Y., Woesik, R., Richmond, R. H., Harrison, P., Fablicius, K.E.: River discharge reduces reef coral diversity in Palau, Marine Pollution Bulletin, 62, 824-831, 2011.

7)工藤将志, 大澤和敏, 佐藤航太郎, 菅和利, 池田駿介: パラオ 共和国ガリキル川流域での土地開発に伴う土砂流出の現地観 測および解析, 土木学会論文集B1(水工学), 69(4), I_937-I_942, 2013.

8) Maalim, F. K., Melesse, A. M., Belmont, P., Gran, K. B.: Modeling the impact of land use changes on runoff and sediment yield in the Le Sueur watershed, Minnesota using GeoWEPP, Catena, 107, 3545, 2013.

9)Renschler, C. S.: Designing geo - spatial interfaces to scaleprocess models: The GeoWEPP approach, Hydrological Processes, 17(5), 1005-1017, 2003.

10) 大澤和敏, 酒井一人, 池田駿介: WEPPモデルによる土䁃侵 食・土砂流出解析, 農業農村工学会誌, 81(12), 13-16, 2013.

11) USDA-ARS National Soil Erosion Research Laboratory: USDAWater Erosion Prediction Project; Hillslope profile and watershed model documentation, NSERL Report No.10, 1995.

12) Nash, J. E., Sutcliffe, J.V.,: River flow forecasting through conceptual models part I - A discussion of principles, Journal of Hydrology, 10, 282-290, 1970.

13) Wischmeier, W.H. and D.D. Smith: Predicting rainfall-erosion losses, USDA Agricultural Handbook No. 537, 1978.

(2013. 9. 30受付) 